Research Article

\title{
Microbial Surface Treatment of Sand with Sporosarcina pasteurii to Improve the Wind Erosion Resistance in Urmia Lake
}

\author{
Hooshang Katebi (D), ${ }^{1}$ Ahmad Fahmi, ${ }^{2,3}$ Ahad Ouria, ${ }^{4}$ Alireza Babaeian Amini, ${ }^{2}$ \\ and Hossein Samadi Kafil (iD) ${ }^{5}$ \\ ${ }^{1}$ Faculty of Civil Engineering, University of Tabriz, Tabriz, Iran \\ ${ }^{2}$ Department of Civil Engineering, Faculty of Engineering, University of Bonab, Bonāb, Iran \\ ${ }^{3}$ University of Tabriz, Tabriz, Iran \\ ${ }^{4}$ Department of Civil Engineering, University of Mohaghegh Ardabilli, Ardabil, Iran \\ ${ }^{5}$ Drug Applied Research Center, Tabriz University of Medical Science, Tabriz, Iran \\ Correspondence should be addressed to Hooshang Katebi; ketabi@tabrizu.ac.ir and Hossein Samadi Kafil; kafilhs@tbzmed.ac.ir
}

Received 17 September 2020; Revised 14 April 2021; Accepted 17 April 2021; Published 5 May 2021

Academic Editor: Claudio Cocozza

Copyright (C) 2021 Hooshang Katebi et al. This is an open access article distributed under the Creative Commons Attribution License, which permits unrestricted use, distribution, and reproduction in any medium, provided the original work is properly cited.

\begin{abstract}
Background. In this research, the potential of the microbially induced carbonate precipitation method for the surface treatment of sand samples of Jabal Kandi dunes, located in the adjacency of Urmia Lake in the northwest of Iran, was considered. Methods. Sporosarcina pasteurii was used as ureolytic bacteria for the preparation of the microbial solution. Corn steep liquor containing urea was used as an inexpensive growth media. The effects of the concentration of cementation solution and the number of treatment cycles were considered. Because of the presence of some hydrolyzed urea in the prepared microbial suspension, two methods of treatment, i.e., the mixed and separate addition of microbial solution and cementation solution to the sand surface, were investigated. Penetration and erosion resistance of the microbial treated sand (sand crust) were measured using a handheld penetrometer and a wind tunnel system. Results. The results showed that the penetration and erosion resistance of the treated sand samples via microbial-induced carbonate precipitation method were improved significantly. In the method with the separate addition of microbial and cementation solutions to the sand surface, a stable sand crust was created on top of the sand. Discussion. This study tried to optimize the microbial application of Sporosarcina pasteurii for surface treatment of sand via microbialinduced carbonate precipitation. Significant and results showed that this method can be used on the field scale for the stabilization of sand dunes. The advanced biotechnology application of this bacterium can be used as an environmentally friendly and safe method instead of other methods.
\end{abstract}

\section{Introduction}

Wind erosion is one of the most important natural serious problems in arid and semiarid regions of the world. Bed and beach of dried lakes with fine-graded materials and wind have the potential for wind erosion $[1,2]$. Because of the wind blow, the particles with $0.1-1 \mathrm{~mm}$ diameter move at the ground level, creating sandhills. Salt dust storms cause significant impacts on both plant growth and their physical health [3]. The water level reduction of Urmia Lake in the northwest of Iran in recent years has led to the shrinkage of the lake area, so sand dunes are developing around the lake border. Some of these dunes have a high potential for erosion and movement to agricultural lands, so the control and stabilization of them are indispensable [1]. Among the different methods used for the control of mobile sand dunes, surface stabilization with oil and chemical mulches and the use of live physical barriers such as vegetation and physical barriers such as fences, ditches, and straw checkerboards with appropriate fencing life could be mentioned [4-6].

One of the methods used for biocementing of sandy soils is microbial-induced carbonate precipitation (MICP) [7-9]. 
This method was used for bioremediation and sequestration of some metals too $[10,11]$. In the MICP method, special species of bacteria are used to produce urease enzyme, leading to the hydrolysis of urea in the presence of calcium ions and the precipitation of calcium carbonate crystals in the pore space of soil [12]. According to chemical relationships, Equations (1) and (2), the urease enzyme acts as a catalyst and hydrolyzes urea to ammonium and carbonate unions. Carbonate anions in the presence of calcium cations lead to producing calcium carbonate between the sand particles and joining them together $[8,13]$. This, in turn, results in the increment of strength and stiffness in granular soils [7, 9].

$$
\begin{aligned}
& \mathrm{CO}\left(\mathrm{NH}_{2}\right)_{2}+2 \mathrm{H}_{2} \mathrm{O} \stackrel{\text { urease }}{\longrightarrow} 2 \mathrm{NH}_{4}^{+}+\mathrm{CO}_{3}^{2-}, \\
& \mathrm{Ca}^{2+}+\mathrm{CO}_{3}^{2-} \longrightarrow \mathrm{CaCO}_{3}(s) .
\end{aligned}
$$

This soil stabilization method was mostly considered indepth, and sand columns were treated with microbial and cementation solutions, and after treatment, the strength of the created sand rock samples was evaluated. In recent years, this method was investigated for surface sand stabilization, too [14-16]. The mechanical resistance and wind erosion modulus of the created sand crust were evaluated in those research studies.

In this study, the microbial surface treatment of sand samples provided from the sand dunes of the Jabal Kandi region in the adjacency of Urmia Lake was considered using the MICP method. This paper has been divided into several stages. First, the effects of different concentrations of the cementation solutions and different numbers of treatment cycles were considered. Next, the methods of adding the treatment solutions to the sand surface were evaluated. The microbial treatment of washed sand to evaluate the effect of the presence of local salts in the sand was executed. Finally, the erosion resistance of microbial treated sand by the wind tunnel test was evaluated and compared to the control untreated sand samples. XRD and SEM analyses of microbial treated sand samples (sand crust samples), as well as their erosion resistance, were considered, too. Evaluating the optimum amount of the cementation solution and the number of treatment cycles via the MICP method for microbial sand stabilization is the most important aim of this research.

\section{Materials and Methods}

2.1. Study Area and Meteorological Data. Urmia Lake, in the northwest of Iran, is the greatest inland lake and one of the most important aquatic ecosystems; it is also one of the major hypersaline lakes in the world [17]. Recent degradation of Urmia Lake was probably caused by reductions in river inflow into the lake and changes in the climate and development of water resources [18]. The water level reduction of Urmia Lake in recent years has led to the shrinkage of the lake area, desertification in shorelines, and the wind erosion of the coastal sand. In addition to the exposure of salt lands, sand dunes are developing around the northwest border of Lake in the Jabal Kandi region (Figure 1). These sand dunes covering an area of $\sim 2000$ ha loom over villages and industrial zones [19]. Sand particles of sand dunes in this region are very fine-graded, and their diameter size is smaller than $300 \mu \mathrm{m}$. The grain-size distribution curve of this sand is presented in Figure 2. The size of $68 \%$ of particles is between 75 and $150 \mu \mathrm{m}$. This area is one of the critical areas with a high potential of erosion and movement to agricultural lands; hence, the movement of these sand dunes to the agricultural lands must be controlled (Figure 3). The amount of calcium carbonate content in the Jabal Kandi sand sample is $90.8 \%$. The amount of $\mathrm{CaCO}_{3}$ in the calcareous sand specimen was measured by the acid-soluble weight loss method [1].

2.2. Microorganism and Cultivation Conditions. For the purpose of the microbial treatment of sand dune via the MICP method, ureolytic bacterium, Sporosarcina pasteurii, was obtained from the Persian Type Culture Collection (PTCC 1645). A culture medium containing $10 \mathrm{~g}$ yeast extract, $10 \mathrm{~g}$ bacto peptone, $10 \mathrm{~g}$ ammonium sulfate, and $20 \mathrm{~g}$ urea per one liter of distilled water was chosen to prepare the inoculation suspension (Asgharzadeh et al. 2016). After cultivation, $S$. pasteurii microbial solution was harvested as an inoculation suspension and stored at $4^{\circ} \mathrm{C}$ prior to use.

For the preparation of the main culture media, corn steep liquor (CSL), the by-product of the Glucosan factory (Qazvin, Iran), was used as an inexpensive nutrient source [20]. The CSL is obtained during the process of extracting starch, oil, and sweeteners from corn. The chemical composition of CSL includes protein and nonfiber carbohydrates. Therefore, CSL could be used as a suitable nutrient source for bacterial cultivation. $100 \mathrm{ml}$ of the CSL broth was diluted with $900 \mathrm{ml}$ distilled water in a $1000 \mathrm{ml}$ glass container to prepare $10 \%$ CSL growth media. The prepared CSL suspension was acidic, and to raise the $\mathrm{pH}$ value, $4 \mathrm{~N} \mathrm{NaOH}$ was added to it to reach the $\mathrm{pH}$ value of 9 . Because of the turbidity of the prepared solution after the $\mathrm{pH}$ adjustment, it was filtered by filter paper to prepare clear growth media, and then, the growth medium was poured in a pair of $1000 \mathrm{ml}$ glass containers so that each container had a $500 \mathrm{ml}$ growth medium. Afterward, they were autoclaved at the temperature of $121^{\circ} \mathrm{C}$ and pressure of 15 (lb/in2) for 15 minutes. Then, $20 \mathrm{~g}$ urea was added to the CSL medium by using the $0.22 \mu \mathrm{m}$ sterilization filter. Next, $50 \mathrm{ml}$ of each prepared growth medium was selected and stored at $4^{\circ} \mathrm{C}$ in the refrigerator as a blank sample to measure the optical density. The CSL-Urea growth media were inoculated with $5 \mathrm{ml}$ of the prepared $S$. pasteurii inoculation suspension. Then, they were incubated for 48 hours at the temperature of $30^{\circ} \mathrm{C}$ in a shaker incubator operating at $170 \mathrm{rpm}$. After incubation, the bacterial suspensions were stored at $4^{\circ} \mathrm{C}$ before use.

The optical density of the grown biomass was measured at $600 \mathrm{~nm}$ with a UV-visible spectrophotometer. The value of optical density at the wavelength of $600 \mathrm{~nm}$ was obtained (2.80). An electrical conductivity device was used to measure the amount of urease activity. For this purpose, $1 \mathrm{~mL}$ of 


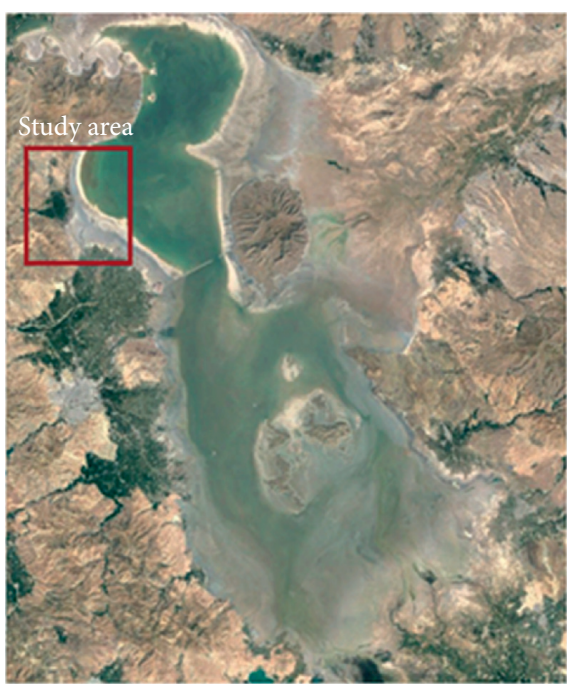

(a)

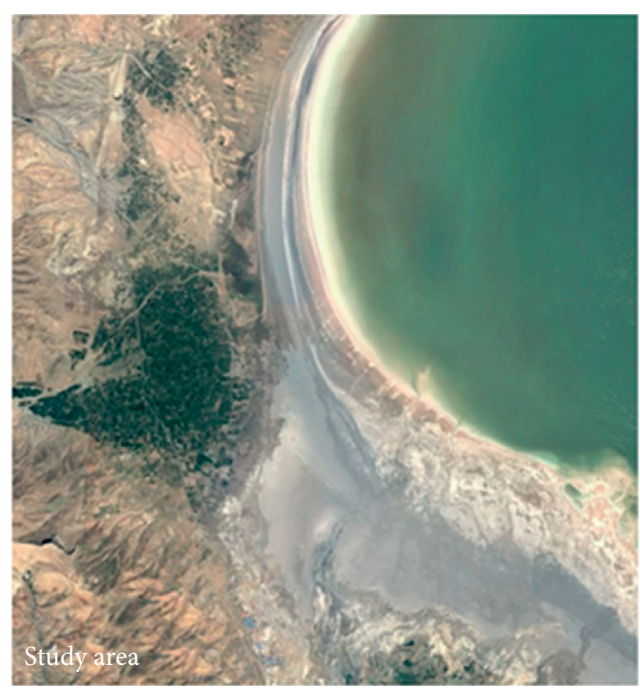

(b)

Figure 1: Study area: Urmia Lake aerial map (a), the aerial map of Jabal Kandi region (b).

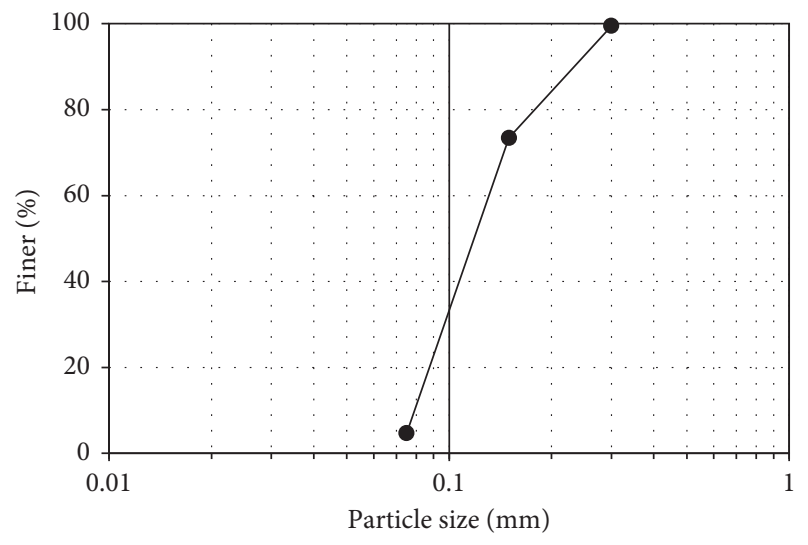

Figure 2: Grain-size distribution curve of Jabal Kandi sand [1].

microbial solution was added to $9 \mathrm{~mL}$ of $1.11 \mathrm{M}$ urea, and the amount of electrical conductivity was measured over 5 minutes at $20^{\circ} \mathrm{C}$ (Whiffin et al. 2007). The value of urease activity was obtained by calculating the slope of conductivity changes versus time in $\mathrm{mS} / \mathrm{cm} / \mathrm{min}$. The amount of urease activity (taking the dilution into account by multiplying to 10) was measured $(0.75 \mathrm{mS} / \mathrm{cm} / \mathrm{min})$.

2.3. Cementation Solution. In this study, microbial and cementation solutions were used for the treatment of sand samples. Cementation solution was composed of equimolar solutions $(0.125,0.25,0.5$, and 1 equimolar) of urea and calcium chloride $\left(\mathrm{CaCl}_{2} \cdot 2 \mathrm{H}_{2} \mathrm{O}\right)$.

2.4. Microbial Treatment Plans. For each treatment plan in all treatment tests (according to Table 1), three similar samples were prepared. Two samples were used to measure the thickness and penetration resistance of the produced crust, and the third sample was used to measure the erosion resistance (introduced in detail in Section 2.5). Microbial solution and cementation solution were added drop by drop uniformly on the sand area. It is added to the text.

2.5. Primary Tests of the Microbial Treatment of Sand Samples. For the performance of the microbial treatment tests, $1100 \mathrm{~g}$ of the dried sand (uniformly graded) was poured into plastic cylindrical containers with a diameter of $10 \mathrm{~cm}$ and the height of $8 \mathrm{~cm}$. Reaching $8 \mathrm{~cm}$ height with $1100 \mathrm{~g}$ of the dried uniformly graded sand in all containers is a confirmation to make sure that all samples have the same physical properties. In each cycle of treatment, $20 \mathrm{~mL}$ microbial solution and then immediately $20 \mathrm{~mL}$ cementation solution were added to the surface of the sand sample separately to percolate rapidly in the sand. In the field scale for surface sand dune stabilization, adding solutions with interval $t$ is time-consuming and is not applicable. These solutions were added drop by drop uniformly on the sand area to ensure the surface uniformity of sand. $40 \mathrm{ml}$ of the microbial and cementation solutions percolated in approximately $2 \mathrm{~cm}$ depth of the sand sample in the container, and after 4 cycles of treatment by $4 \times 40 \mathrm{ml}$ of solutions, the sand sample in the container became wetted. Each treated sample kept at room temperature before beginning the time of the next cycle. The interval time between all the treatment cycles was 24 hours. To evaluate the effect of the concentration of the cementation solution and the number of the treatment cycles on the quality of surface treatment of sand, primary treatment tests of the microbial treatment of sand samples were planned according to Table 1 (Groups 1-4). After the stabilization operation and before the improvement measurements, all the treated samples were kept to fully dry for the test, at room temperature for a week.

2.6. Microbial Treatment of Sand by Two Different Methods of Adding. In some research studies involving the microbial soil treatment via the MICP method, while urea was used in 


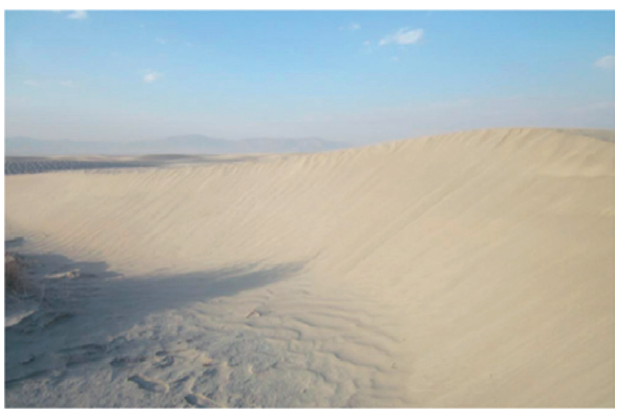

(a)

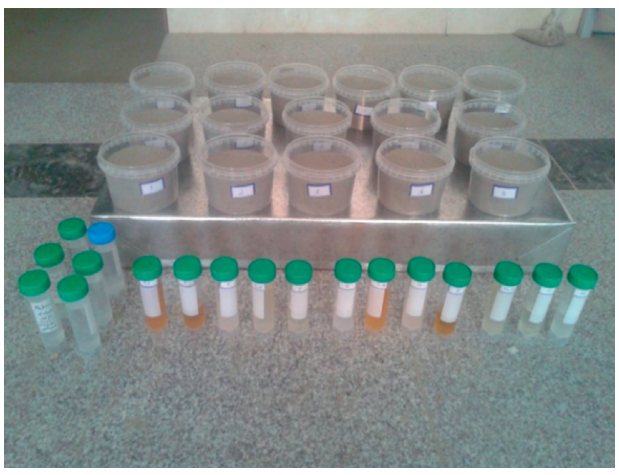

(c)

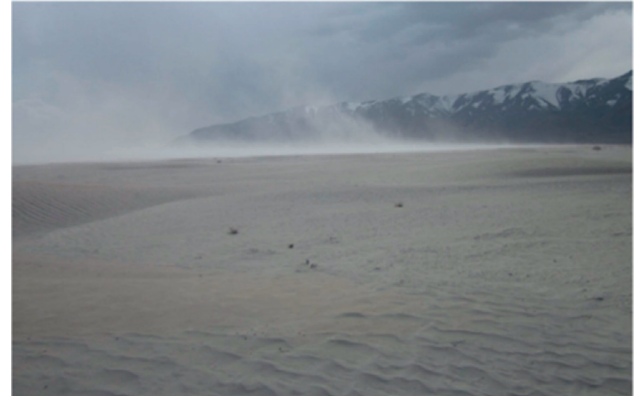

(b)

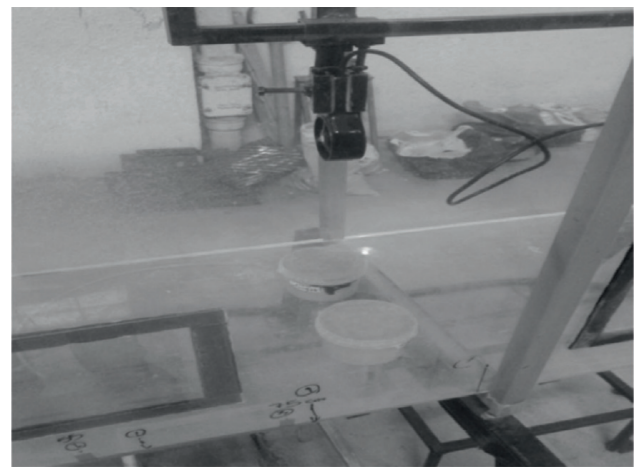

(d)

Figure 3: Sand dunes of Jabal Kandi region (a), wind erosion of sand and movement of sand dunes in Jabal Kandi region (b). Samples with its plastic containers (c), samples inside wind tunnel $(\mathrm{d})$.

TABLE 1: Microbial treatment of sand samples.

\begin{tabular}{|c|c|c|c|c|c|c|}
\hline Treatment group & & Sand samples & Number of samples & Cycle numbers & Concentration (equimolar) & Adding method \\
\hline \multirow{16}{*}{ Primary treatment tests } & \multirow{4}{*}{ Group 1} & Natural sand & 3 & 1 & 0.125 & Separated \\
\hline & & Natural sand & 3 & 1 & 0.250 & Separated \\
\hline & & Natural sand & 3 & 1 & 0.500 & Separated \\
\hline & & Natural sand & 3 & 1 & 1.000 & Separated \\
\hline & \multirow{4}{*}{ Group 2} & Natural sand & 3 & 2 & 0.125 & Separated \\
\hline & & Natural sand & 3 & 2 & 0.250 & Separated \\
\hline & & Natural sand & 3 & 2 & 0.500 & Separated \\
\hline & & Natural sand & 3 & 2 & 1.000 & Separated \\
\hline & \multirow{4}{*}{ Group 3} & Natural sand & 3 & 3 & 0.125 & Separated \\
\hline & & Natural sand & 3 & 3 & 0.250 & Separated \\
\hline & & Natural sand & 3 & 3 & 0.500 & Separated \\
\hline & & Natural sand & 3 & 3 & 1.000 & Separated \\
\hline & \multirow{4}{*}{ Group 4} & Natural sand & 3 & 4 & 0.125 & Separated \\
\hline & & Natural sand & 3 & 4 & 0.250 & Separated \\
\hline & & Natural sand & 3 & 4 & 0.500 & Separated \\
\hline & & Natural sand & 3 & 4 & 1.00 & Separated \\
\hline \multirow{2}{*}{ Adding method } & \multirow{2}{*}{ Group 5} & Natural sand & 3 & 4 & 0.25 & Separated \\
\hline & & Natural sand & 3 & 4 & 0.25 & Mix \\
\hline \multirow{2}{*}{ Salt effect } & \multirow{2}{*}{ Group 6} & Natural sand & 3 & 4 & 0.25 & Separated \\
\hline & & Washed sand & 3 & 4 & 0.25 & Separated \\
\hline
\end{tabular}

the cementation solution (for example, an equimolar solution of urea and calcium chloride), it has also been employed in the culture media as one of the nutrient materials [21, 22]. Ureolytic bacteria use urea as a nitrogen source (nutrient source); even by producing the ammonium ions, it causes the increment of the $\mathrm{pH}$ [22]. In this study, because of the presence of $2 \%$ urea in the culture media
(CSL-Urea), the cultivated bacterial solution contained some hydrolyzed urea; hence, an immediate biochemical reaction of the hydrolyzed urea (of the cultivated media) with some part of the calcium chloride ions (of the cementation solution) could lead to the immediate creation of the milky suspension. This milky suspension which contains the calcium carbonate particles in the pore volume of the sand 
grains does not act as cement between them. Besides, in the presence of bacterial urease enzyme, the biochemical reaction between the urea of the cementation solution and remained calcium ions of it could cause the slow precipitation of the cohesive calcium carbonate as cement between the sand grains.

In this research, treatment of the sand samples was done using two additional methods including separated and mixed adding of microbial and cementation solutions. In the first method, the cementation solution was added to the sand surface after adding the microbial cementation. In this method, the quick biochemical reaction of the hydrolyzed urea and calcium chloride occurred inside the sand (the milky suspension was created inside the sand sample), and a thin milky-color layer was not created on the surface of the sand. In the second method, the microbial and cementation solutions were mixed before use. Thereupon, the produced viscous solution, which could not percolate in the sand depth, was added drop by drop to the surface of the sand in each cycle, leading to the creation of a thin milky-color layer on the surface of the sand. To evaluate the effect of the adding method on the quality of surface treatment of sand, Group 5 tests were planned according to Table 1. The concentration of the cementation solution and the number of treatment cycles were selected ( 0.25 equimolar and 4 , respectively). After the stabilization operation and before the evaluative tests of improvement, all the treated samples were kept at room temperature for a week.

2.7. Microbial Treatment of the Natural (Unwashed) and Washed Sand Samples. In the previous tests, microbial treatment of natural sand samples was investigated. According to the presence of salts $(\mathrm{NaCl})$ in the sand dunes of Jabal Kandi region, because of the adjacency to Urmia Lake, to consider the positive or negative effects of the salts in the process of microbial stabilization of sand dunes via the MICP method, some sand was poured on the no. 200 $(75 \mu \mathrm{m})$ sieve and vibrated on the shaker for 30 minutes to dissolve and remove the salt. The remaining sand was washed on the same sieve to eliminate all salt of sand. The weight of particles containing all salt content and sand particles finer than $75 \mu \mathrm{m}$, was less than $5 \%$. The washed sand was dried in the oven. To evaluate the effect of the presence of salts in sand samples on the quality of surface treatment of sand, Group 6 tests were planned according to Table 1. The concentration of the cementation solution and the number of treatment cycles were selected ( 0.25 equimolar and 4, respectively). After the stabilization operation and before the evaluative tests for improvement, all the treated samples were kept at room temperature for a week.

2.8. The Procedure of Improvement Measurements. After the microbial treatment of the three similar samples of each plan, the amount of penetration resistance was measured for the first dry sample. Then, it was taken out of the container, and after removing the lower loose parts by hand (without any rubber), the thickness of the dry sand crust was measured. Then, the second sample was soaked in water, and after the expulsion of the unstable parts, the thickness of the stable sand crust was measured, too. In addition, it was saturated in water for 24 hours, and then, its penetration resistance was measured (a single measurement per sample in the center of it). In this research, a handheld penetrometer device was used for the measurement of the penetration resistance of the produced sand crust via the MICP method. This device provides an index of the shear resistance [23]. This instrument could measure the unconfined shear strength of soils up to $4.5 \mathrm{~kg} / \mathrm{cm}^{2}$ ( $\left.450 \mathrm{kPa}\right)$. This instrument was used by some researchers [16, 22, 24, 25].

For the wind tunnel test, the third sample was saturated with water for 24 hours and dried at room temperature again for another week, and then, the erosion resistance of it was measured. In this study, the maximum velocity of wind provided by the wind tunnel device was $30 \mathrm{~m} / \mathrm{s}$. Before the placement in the wind tunnel, the mass of each treated sand sample was weighed; then, each sample was set in the wind tunnel against the wind flow with a velocity of $30 \mathrm{~m} / \mathrm{s}$ for 5 minutes. Every treated sample with its plastic container (without taking out from the container) was placed in the wind tunnel, and the surface of the sample interacted with the wind (Figure 3). Afterward, the mass of the sample was weighed again. In addition, this test was performed for control samples (containing the natural untreated sand) at $15,20,25$, and $30 \mathrm{~m} / \mathrm{s}$ velocities for 5 minutes. After computing the reduced mass of each sample, the amount of wind erosion modulus in $\mathrm{g} \cdot \mathrm{m}^{-2} \cdot \mathrm{min}^{-1}$ was calculated by estimating the reduced mass, flow time, and sample area. When the amount of wind erosion modulus is less, the erosion resistance of the sample is higher.

2.9. Analysis of Sand and Microbial-Treated Sand (Sand Crust). The natural sand sample of the sand dunes of the Jabal Kandi region, prepared from the surface of dunes, was analyzed by XRD examination. In addition, the morphology and type of precipitated calcium carbonate crystals of the microbial treated sand crust (treated in 4 cycles) were determined by SEM and XRD examinations.

\section{Results and Discussion}

3.1. The Results of Primary Treatment Tests. Given the limitation of the maximum measurable penetration resistance to $450 \mathrm{kPa}$ by the penetrometer, " $450 *$ " in the graphs of this study shows that the obtained penetration resistance was higher than $450 \mathrm{kPa}$. In this study, according to Figures 4 and 5 , the results of the microbial treatment of the sand samples show that after the soaking of each sample, the amounts of thickness and penetration resistance were reduced compared to the same dry sample. According to Figure 4, for the samples with 2 cycle treatments, the thickness of the crusts was reduced to $69-80 \%$ after soaking in water. Also, according to Figure 5, penetration resistance of the crusts was reduced to $64-86 \%$ after soaking in water. The least reduction is related to the samples treated with 0.5 and 1 equimolar cementation solution. This is because of the presence of some uncemented loose parts containing the 


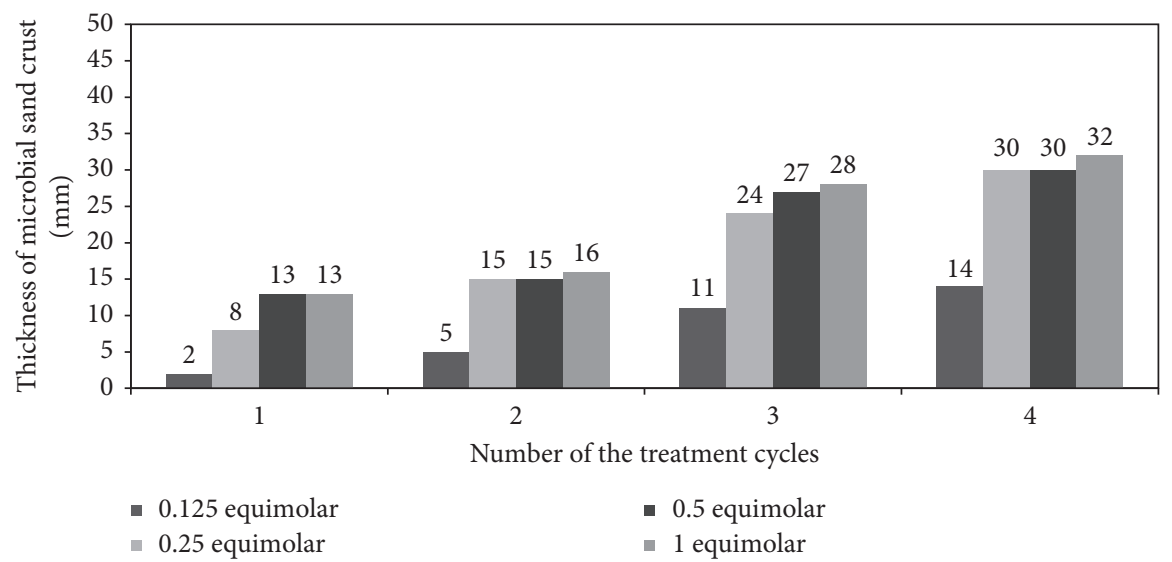

(a)

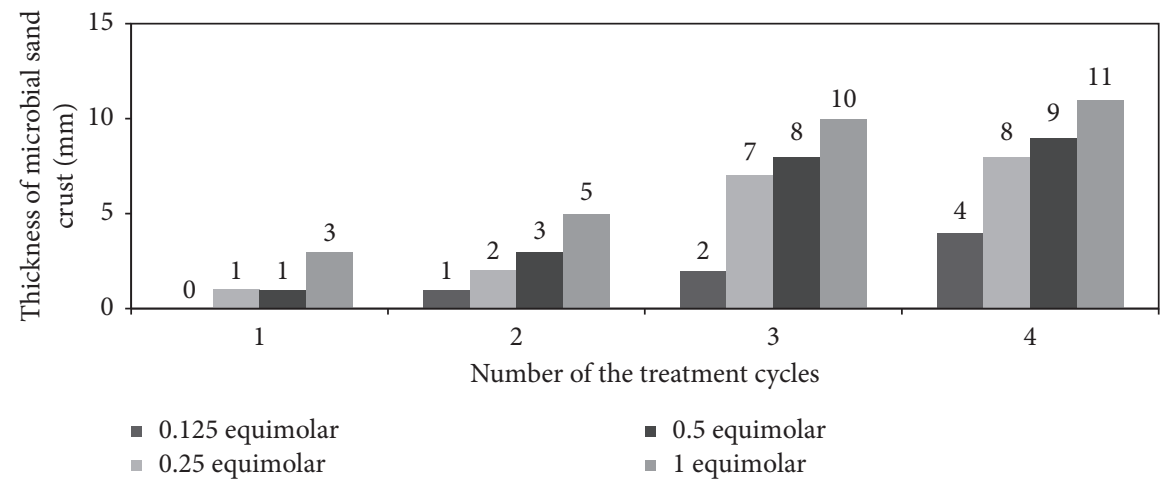

(b)

FIGURE 4: Thickness of the produced sand crust samples before soaking in water (a), after soaking in water and the expulsion of the unstable parts (b).

unstable $\mathrm{CaCO}_{3}, \mathrm{CaCl}_{2}$, and growth medium materials in the lower part of the dried samples. These unstable parts are dissolving or decomposing during soaking. The results revealed that the penetration resistance and thickness of the produced sand crust samples were increased by the increment of the treatment cycles and cementation solution concentrations. In addition, the higher values of the sand crust thickness and penetration resistance were gained after 3 cycles of treatment; hence, it could be concluded that at least 3 cycles of treatment would be needed for producing the appropriate sand crust.

According to Figures 4(b) and 5(b), the maximum thickness of stable sand crust (after soaking in water) was $11 \mathrm{~mm}$ and the maximum penetration of it was $250 \mathrm{kPa}$, which was obtained for treatment with 1 equimolar concentration of the cementation solution and 4-cycle treatment. These values for 0.5 equimolar concentration of the cementation solution and 4-cycle treatment were $9 \mathrm{~mm}$ and $225 \mathrm{kPa}$, respectively. These values are a little lower than the maximum values. Hence, based on the low consumption of urea and calcium chloride, the value of 0.50 equimolar could be regarded as the appropriate concentration of cementation solution for the creation of the microbial sand crust.

The creation of sand crust layer is in conformity with the results of the two other research articles [14, 15] which considered the surface treatment of well-graded and poor- graded sand via the MICP method and used the wind tunnel test for the quantitative assessment of treatment. In both types of sand, the crust-like layer was created on the top of the sand. The article [14] investigated sand dune stabilization via the MICP method in the field scale, using the surface spray of microbial and nutrient amendment solutions. After treatment, a sandstone-like crust was created.

3.2. Adequate Adding Method for the Microbial Treatment of Sand. The results of the microbial treatment of sand with two methods, including the mixed and separate addition of microbial and cementation solutions to the sand, showed that the separated method had more efficiency than the mixed method, yielding more penetration resistance. In the mixed method, the major part of the produced calcium carbonate was precipitated as a milky layer on the surface of the sand sample. For the treated sand with the mixed method, after soaking in water, it was collapsed entirely (no sand crust remained). However, at the same time, for the samples treated by the separate method, after soaking in water and collapse of the unstable down parts, the thickness of the stable sand crust was $8 \mathrm{~mm}$.

3.3. Influence of Salts Existing in the Natural Sand in the Process of Microbial Treatment. On the field scale, the possibility of sand washing before microbial treatment does 


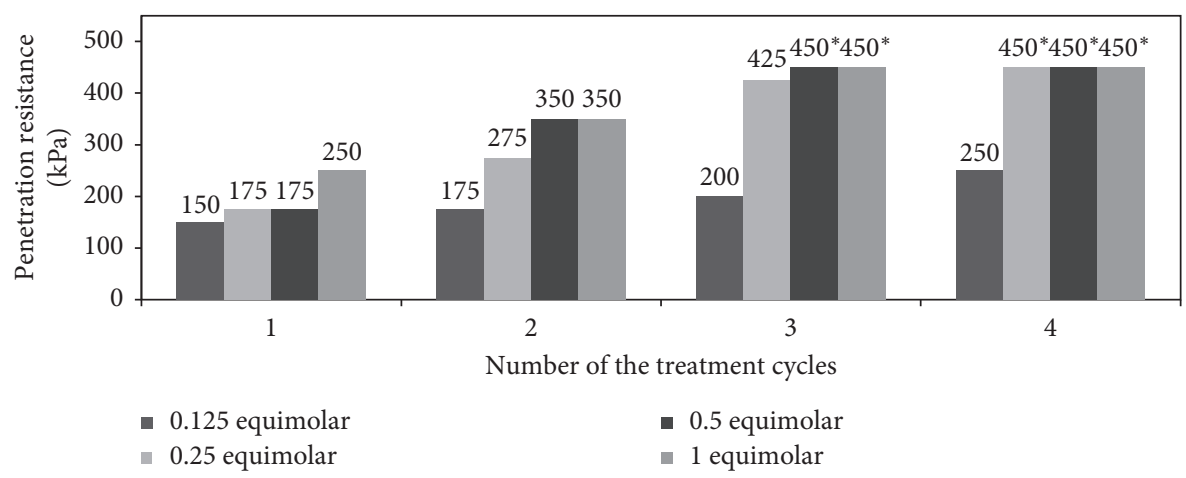

(a)

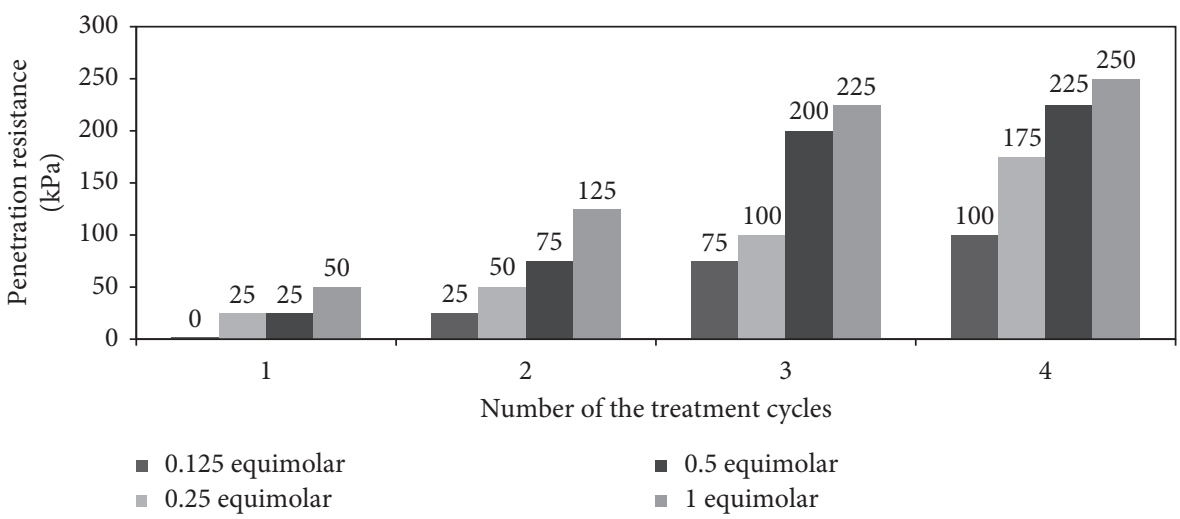

(b)

FIGURE 5: Penetration resistance of the produced sand crust samples before soaking in water (a), after soaking in water and the expulsion of the unstable parts (b).

not exist from the economical aspect. In this research, the purpose of the microbial treatment of the washed sand was to compare the penetration resistance of washed sand with that of the natural unwashed sand to consider the probable effect of salts existing in the sand on the process of microbial treatment. There is no difference between the penetration resistance of the washed and unwashed sand under the equal condition of the treatment. In both cases, the thickness of the stable sand crust was 8 millimeters after soaking in water. Hence, the presence of salts in the natural sands had no negative effect on the process of the microbial treatment of sand (of course, by using the bacteria and the method of this research).

\subsection{Surface Erosion Resistance of the Natural Untreated Sand} Samples against the Wind Blow. The maximum wind velocity graph for Kahriz synoptic stations was prepared according to the meteorological data accessible in IR of the Iran Meteorological Organization [26]. Kahriz station is very close to the Jabal Kandi region. According to Figure 6(a), the amount of the maximum wind velocity at Kahriz synoptic station reached $46 \mathrm{~m} / \mathrm{S}$ in 2014. According to Figure 6(b), the results of the wind tunnel test showed that the amounts of the wind erosion modulus and mass reduction for the natural untreated sand samples of the Jabal Kandi region were increased strongly with wind velocity increment. In this study, the maximum velocity in the used wind tunnel device was limited to $30 \mathrm{~m} / \mathrm{s}$; it was predictable that at larger amounts of wind velocity (upper than $30 \mathrm{~m} / \mathrm{s}$ ), the amount of wind erosion modulus would be much more.

3.5. Surface Erosion Resistance of the Treated Sand Samples against the Wind Blow. In this study, for samples treated via the MICP method, because of the creation of the sand crust at the top of them, the amounts of the wind erosion modulus and mass reduction were reduced significantly. So, in most of the treated samples, after wind tunnel tests with a velocity of $30 \mathrm{~m} / \mathrm{s}$ for 5 minutes, the value of the wind erosion modulus was reduced to zero (for untreated natural sand sample, this value was $\left.2828 \mathrm{~g} \mathrm{~m}^{-2} \cdot \mathrm{min}^{-1}\right)$. Only, in the samples with 1 and 2 cycles of treatment and too low concentration for the cementation solutions ( 0.125 equimolar), the values of the wind erosion modulus were reduced to nonzero amounts of 1273 and $968 \mathrm{~g} \mathrm{~m}^{-2} \cdot \mathrm{min}^{-1}$, respectively. Samples treated by adding the viscose solution of the mixed microbial and cementation solutions onto the surface of the sand in 4 cycles were examined at the wind tunnel test, too. In spite of no sand crust creation, after the wind tunnel test, the amounts of wind erosion modulus were reduced significantly to 2 grams because of the presence of the milky layer on the top of them.

In spite of that, the microbial treatment of sand via the MICP method with 1 cycle led to the significant reduction of 


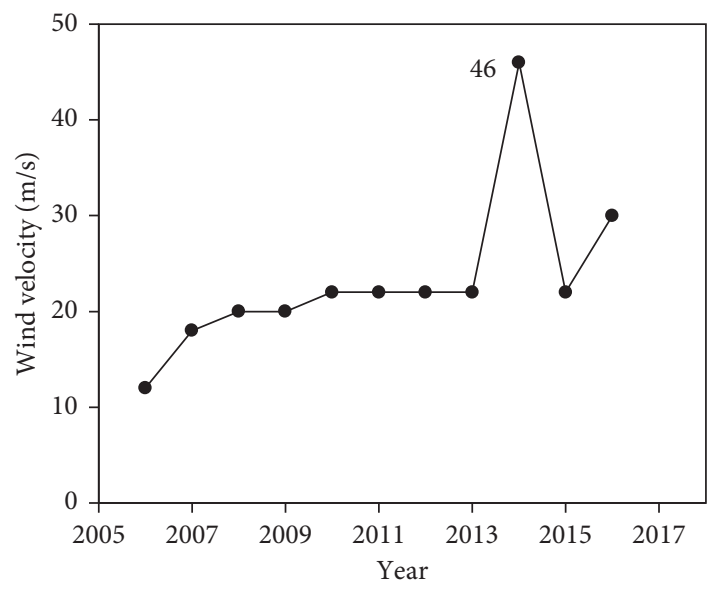

(a)

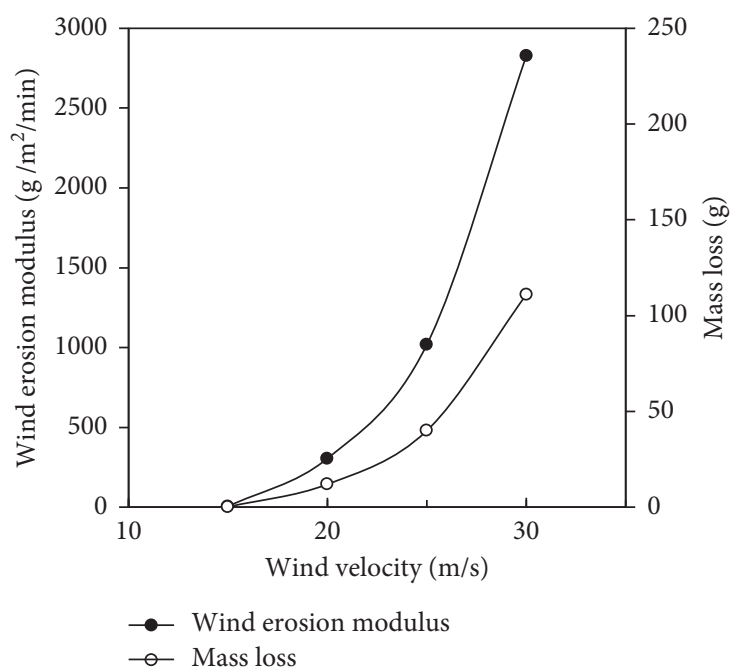

(b)

Figure 6: Maximum annual wind velocity at Kahriz synoptic station (a) and Mass reduction and wind erosion modulus of Jabal Kandi sand, the wind tunnel test (b).

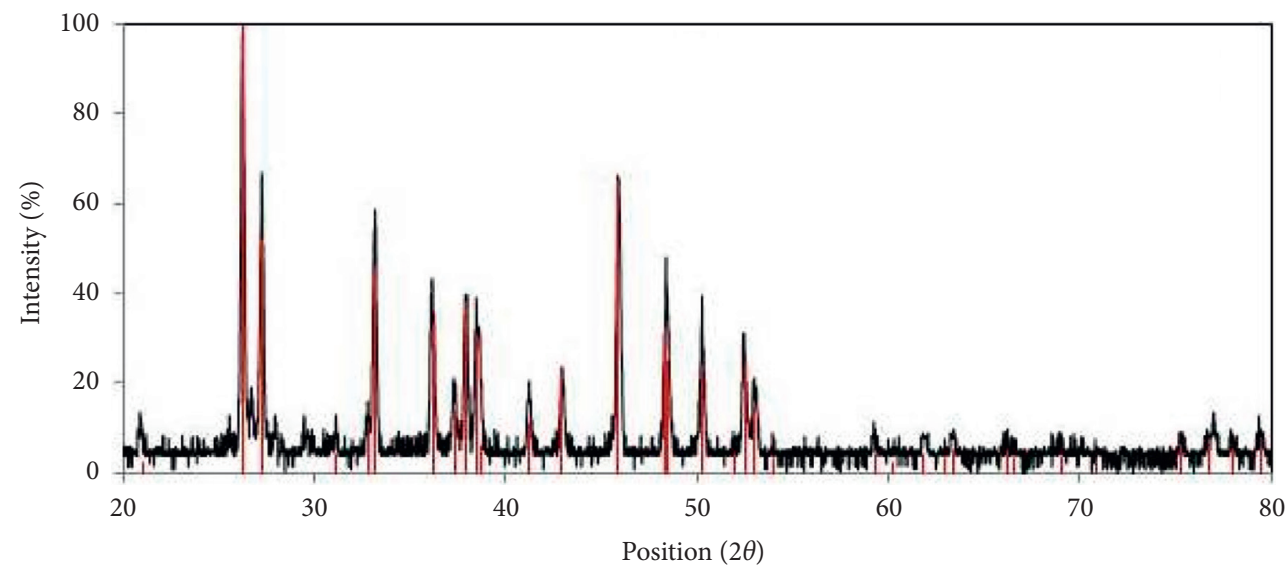

- Aragonite

(a)

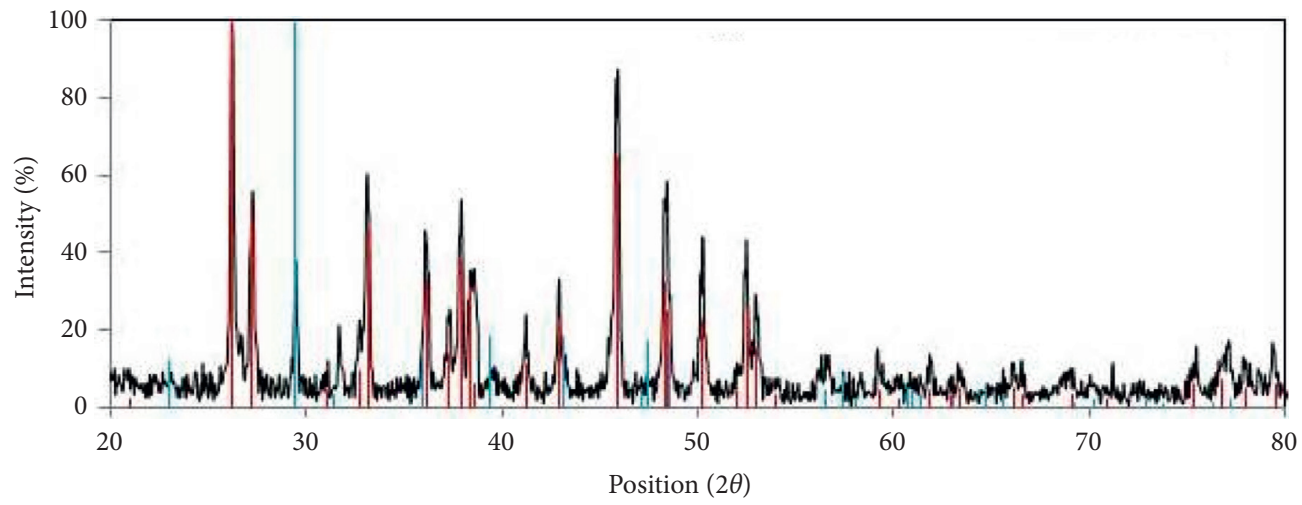

— Aragonite

— Calcite

(b)

FIGURE 7: XRD analysis of the natural untreated sand (a), XRD analysis of the sand crust produced via microbial treatment (b). 


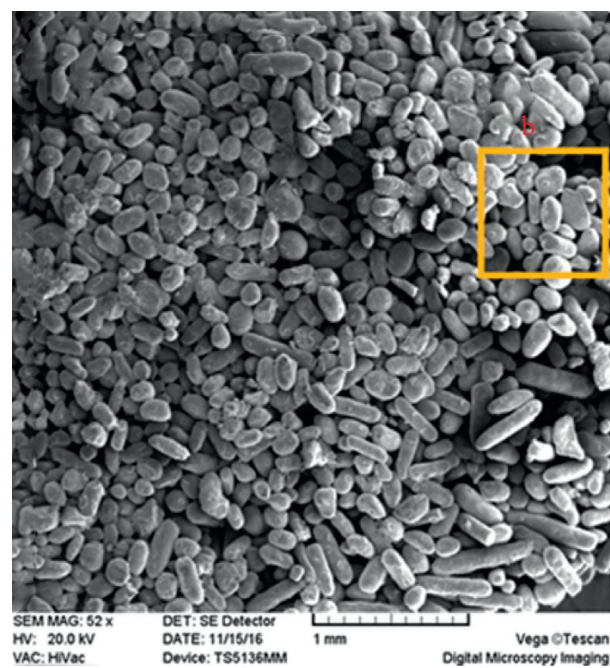

(a)

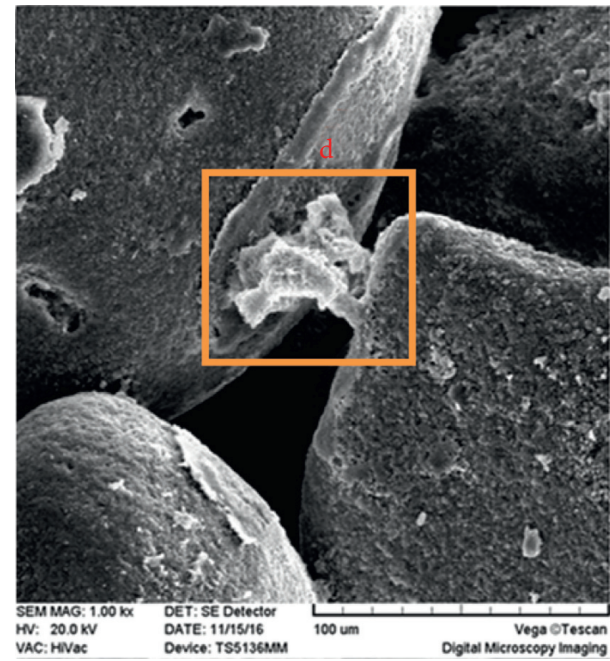

(c)

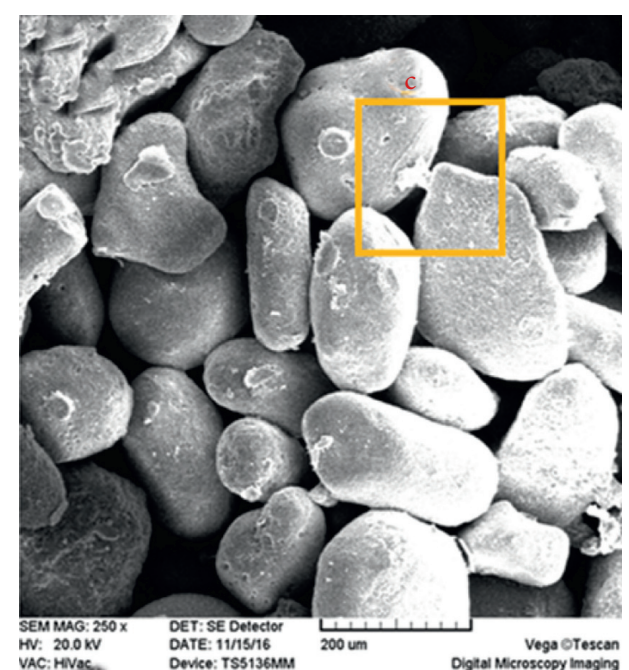

(b)

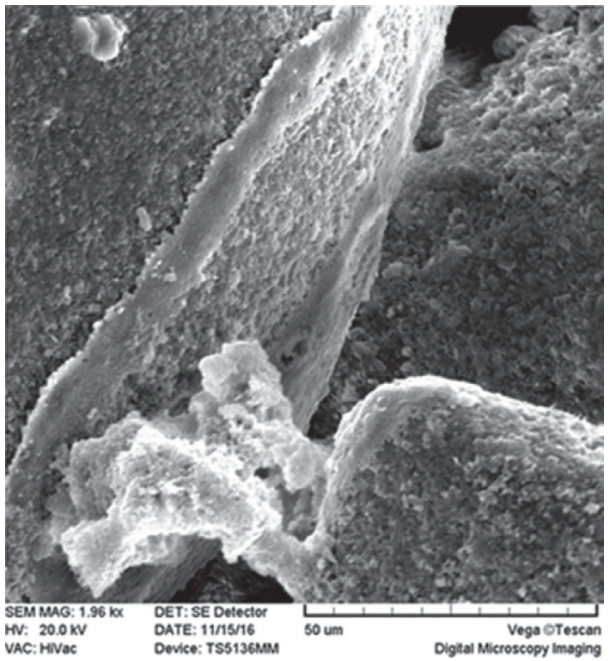

(d)

Figure 8: SEM images of the Microbial treated sand (stable sand crust) at $52 \times(a), 250 \times(b), 1000 \times(c)$ and $1960 \times(d)$ magnifications. Images show the microbial-induced calcium carbonate bridges between the sand grains.

wind erosion modulus and, consequently, the increment of the erosion resistance of sand; however, for the creation of a stable sand crust with acceptable penetration resistance and thickness values, 3 cycles of treatment would be needed. Some researchers used the wind tunnel test for the quantitative assessment of one-cycle microbial treatment of sand via the MICP method, so the results showed that microbiological treatment on the soil surface reduced the wind erosion amount $[16,27]$. From the aspect of erosion resistance increment, the result of this study is in conformity with their results. The fundamental result is the reduction of the wind erosion modulus to zero by use of the microbial suspension containing hydrolyzed urea, even by low amounts of the treatment cycles and cementation solution concentrations.

3.6. Morphology of the Calcium Carbonate Minerals of the Precipitated Sand Crust. Three crystal forms of calcium carbonate with a similar formula $\left(\mathrm{CaCO}_{3}\right)$ are calcite, vaterite, and aragonite. The most stable crystal of calcium carbonate is calcite [28]. Ureolytic bacteria could induce calcite and vaterite crystal polymorphs [22, 29-33]. As mentioned, a sample of the microbial treated sand sample (stable sand crust) was treated in 4 cycles and examined by SEM and XRD examinations. As mentioned, the amount of calcium carbonate content in the Jabal Kandi untreated sand sample was $90.8 \%$. According to Figure 7, XRD analysis for both natural untreated sand and microbial-treated sand (stable sand crust) showed that peaks were strongly matched to aragonite, which could be related to the sand grains, not the microbially induced precipitations. The amount of calcite mineral in the microbial-treated sand is much more compared to the natural untreated sand; no vaterite mineral was recognized in both of the treated and untreated sand samples; hence, the microbialinduced precipitated minerals are calcite. According to Figure 8, SEM showed that microbial-induced calcium carbonate precipitations joined the sand grains as bridges. Some $\mathrm{CaCO}_{3}$ was precipitated on the surface of sand grains too. 
In most researches, the stabilization and cementation of silica sands have been studied via the MICP method, such as Ottawa sand $[9,34]$ and the Itterbeck sand $[13,35,36]$. The results of this study showed that the MICP method could be used for surface stabilizing of fine-graded aragonitic sand.

\section{Conclusions}

Given the high potential of the wind erosion of sand and movement of sand dunes to the agricultural lands in Jabal Kandi region in the adjacency of Urmia Lake, continuing sand dune stabilizing projects in this region seems to be necessary. In particular, the erosion potential of sand in this region increases strongly by wind velocity increment. The microbial treatment (MICP method) could be the suitable method for the creation of the biocrust on the top of the surface of the sand of the Jabal Kandi region and prevention of the mobility of sand dunes. The amount of the wind erosion modulus reduces significantly in the microbialtreated sand because of the creation of sand crust on top of the sample. The presence of salts in the natural sans samples had no negative effect on the process of the microbial treatment of sand. In most of the treatment plans, microbial treatment of sand with one cycle leads to the creation of the thin sand crust on the top of the sand and the significant increment of the erosion resistance, but it will not have enough penetration resistance and stability. In terms of the low stability of this thin sand crust (created by 1 cycle of treatment), it could act as a degradable sand crust for preventing the sand dune movement and extension of vegetation as a live windbreaker. However, 3-4 cycles of microbial treatment with a low concentration of cementation solution ( 0.25 and 0.5 equimolar) would lead to the creation of stable sand crust with acceptable penetration resistance, but the execution of 3-4 cycles of microbial treatment in the field scale might not be economic. Reduction of the wind erosion modulus to zero by the use of the microbial suspension containing hydrolyzed urea, even by low amounts of the treatment cycles and cementation solution concentrations, is one of the important results of this study. Stabilization of sand via MICP is a new method and after further optimization of solutions and methods can be used in the field scale, especially for stabilization of sand dunes. In this study, the CSL was used as an inexpensive nutrient medium compared to the yeast extract and peptone. Therefore, from the aspect of the economy, largescale field projects such as surface treatment of sand dunes via the MICP are applicable by using the CSL in the growth media.

\section{Data Availability}

All data and materials are available upon request from authors.

\section{Conflicts of Interest}

The authors declare that they have no conflicts of interest.

\section{Authors' Contributions}

Hooshang Katebi and Ahmad Fahmi contributed equally to this work.

\section{Acknowledgments}

The authors thank Dr. Alireza Seyed Goreishi from the Environment Bureau of West Azarbaijan for the environmental data provided for the Jabal Kandi region and $\mathrm{Mr}$. Mohammadreza Abbasi Aval for the wind tunnel test. The authors thank Mr. Seyed Ali Koohestani from the Glucosan Company for providing corn steep liquor, Mr. Kamal Mirzaaghazadeh for providing assistance in the SEM analysis, and Mrs. Mahtaj Chehreh for literary editing. This study was supported By Orumieh Lake Restoration Program (ULRP) and Drug Applied Research Center, Tabriz University of Medical Sciences.

\section{References}

[1] H. Katebi, A. Fahmi, H. Samadi Kafil, and M. Hajialilue Bonab, "Stabilization of calcareous sand dunes using phosphoric acid mulching liquid," Journal of Arid Environments, vol. 148, pp. 34-44, 2018.

[2] G. Issanova, J. Abuduwaili, O. Galayeva, O. Semenov, and T. Bazarbayeva, "Aeolian transportation of sand and dust in the Aral Sea region," International Journal of Environmental Science and Technology, vol. 12, no. 10, pp. 3213-3224, 2015.

[3] D. Liu, J. Abuduwaili, J. Lei, G. Wu, and D. Gui, "Wind erosion of saline playa sediments and its ecological effects in Ebinur Lake, Xinjiang, China," Environmental Earth Sciences, vol. 63, no. 2, pp. 241-250, 2011.

[4] K. Pye and H. Tsoar, Aeolian Sand and Sand Dunes, Springer Science \& Business Media, Berlin, Germany, 2008.

[5] F. El-Baz, "The formation and motion of dunes and sand seas," in Physics of Desertification, pp. 70-93, Springer, New York, NY, USA, 1986.

[6] W. Wu, D. Zhang, L. Tian, S. Gao, M. Zhang, and X. Zhou, "Erosion-deposition characteristics and fencing life of straw checkerboard in alpine sandy lands," Environmental Engineering Science, vol. 36, no. 1, 2019.

[7] V. S. Whiffin, "Microbial $\mathrm{CaCO}_{3}$ precipitation for the production of biocement," Ph.D. Thesis, Murdoch University, Perth, Australia, 2004.

[8] L. A. Van Paassen, "Biogrout, ground improvement by microbial induced carbonate precipitation," Ph.D. Thesis, Delft University of Technology, Delft, Netherlands, 2009.

[9] J. T. DeJong, M. B. Fritzges, and K. Nüsslein, "Microbially induced cementation to control sand response to undrained shear," Journal of Geotechnical and Geoenvironmental Engineering, vol. 132, no. 11, pp. 1381-1392, 2006.

[10] C.-H. Kang, J.-H. Choi, J. Noh, D. Y. Kwak, S.-H. Han, and J.-S. So, "Microbially induced calcite precipitation-based sequestration of strontium by Sporosarcina pasteurii WJ-2," Applied Biochemistry and Biotechnology, vol. 174, no. 7, pp. 2482-2491, 2014.

[11] C.-H. Kang, S.-H. Han, Y. Shin, S. J. Oh, and J.-S. So, "Bioremediation of $\mathrm{Cd}$ by microbially induced calcite precipitation," Applied Biochemistry and Biotechnology, vol. 172, no. 6, pp. 2907-2915, 2014.

[12] A. Al Qabany, K. Soga, and C. Santamarina, "Factors affecting efficiency of microbially induced calcite precipitation," 
Journal of Geotechnical and Geoenvironmental Engineering, vol. 138, pp. 992-1001, 2011.

[13] V. S. Whiffin, L. A. Van Paassen, and M. P. Harkes, "Microbial carbonate precipitation as a soil improvement technique," Geomicrobiology Journal, vol. 24, no. 5, pp. 417-423, 2007.

[14] M. G. Gomez, B. C. Martinez, J. T. DeJong et al., "Field-scale bio-cementation tests to improve sands," Proceedings of the Institution of Civil Engineers-Ground Improvement, vol. 168, no. 3, pp. 206-216, 2015.

[15] S. C. Bang, S. H. Min, and S. Bang, "Application of microbiologically induced soil stabilization technique for dust suppression," International Journal of Geo-Engineering, vol. 3, pp. 27-37, 2011.

[16] M. Maleki, S. Ebrahimi, F. Asadzadeh, and M. Emami Tabrizi, "Performance of microbial-induced carbonate precipitation on wind erosion control of sandy soil," International Journal of Environmental Science and Technology, vol. 13, no. 3, pp. 937-944, 2016.

[17] M. Zarghami, "Effective watershed management; case study of Urmia Lake, Iran," Lake and Reservoir Management, vol. 27, no. 1, pp. 87-94, 2011.

[18] S. Shadkam, F. Ludwig, P. Van Oel, Ç. Kirmit, and P. Kabat, "Impacts of climate change and water resources development on the declining inflow into Iran's Urmia Lake," Journal of Great Lakes Research, vol. 42, no. 5, pp. 942-952, 2016.

[19] H. Ahmady-Birgani, E. Agahi, S. J. Ahmadi, and M. Erfanian, "Sediment source fingerprinting of the lake Urmia sand dunes," Scientific Reports, vol. 8, p. 206, 2018.

[20] A. Fahmi, H. Katebi, M. Hajialilue Bonab, and H. Samadi Kafil, "Microbial sand stabilization using corn steep liquor culture media and industrial calcium reagents in cementation solutions," Industrial Biotechnology, vol. 14, no. 5, pp. 270-275, 2018.

[21] L. Zhong and M. R. Islam, "A new microbial plugging process and its impact on fracture remediation," in Proceedings of the SPE Annual Technical Conference and Exhibition, pp. 703715, Dallas, TX, USA, October 1995.

[22] S. Al-Thawadi, High Strength In-Situ Biocementation of Soil by Calcite Precipitating Locally Isolated Ureolytic Bacteria, Murdoch University, Perth, Australia, 2008.

[23] L. A. Rahmatian and P. T. Metzger, "Soil test apparatus for lunar surfaces," in Proceedings of the 12th Biennial International Conference on Engineering, Construction, and Operations in Challenging Environments; and Fourth NASA/ARO/ ASCE Workshop on Granular Materials in Lunar and Martian Exploration, Honolulu, HI, USA, March 2010.

[24] J. Liu, B. Shi, Y. Lu et al., "Effectiveness of a new organic polymer sand-fixing agent on sand fixation," Environmental Earth Sciences, vol. 65, no. 3, pp. 589-595, 2012.

[25] L. Cheng and R. Cord-Ruwisch, "In situ soil cementation with ureolytic bacteria by surface percolation," Ecological Engineering, vol. 42, pp. 64-72, 2012.

[26] Organization IoIM, Iran: IR of Iran Meteorological Organization, Iran Meteorological Organization, Tehran, Iran, 2016.

[27] V. Stabnikov, J. Chu, A. N. Myo, and V. Ivanov, "Immobilization of sand dust and associated pollutants using bioaggregation," Water, Air, \& Soil Pollution, vol. 224, pp. 1-9, 2013.

[28] K. Sarayu, N. R. Iyer, and A. R. Murthy, "Exploration on the biotechnological aspect of the ureolytic bacteria for the production of the cementitious materials-a review," Applied Biochemistry and Biotechnology, vol. 172, no. 5, pp. 23082323, 2014.
[29] S. Wei, H. Cui, Z. Jiang, H. Liu, H. He, and N. Fang, "Biomineralization processes of calcite induced by bacteria isolated from marine sediments," Brazilian Journal of Microbiology, vol. 46, no. 2, pp. 455-464, 2015.

[30] S. Sanchez-Moral, J. C. Canaveras, L. Laiz, C. Sáiz-Jiménez, J. Bedoya, and L. Luque, "Biomediated precipitation of calcium carbonate metastable phases in hypogean environments: a short review," Geomicrobiology Journal, vol. 20, no. 5, pp. 491-500, 2003.

[31] S. Stocks-Fischer, J. K. Galinat, and S. S. Bang, "Microbiological precipitation of $\mathrm{CaCO}_{3}$," Soil Biology and Biochemistry, vol. 31, no. 11, pp. 1563-1571, 1999.

[32] K. L. Bachmeier, A. E. Williams, J. R. Warmington, and S. S. Bang, "Urease activity in microbiologically-induced calcite precipitation," Journal of Biotechnology, vol. 93, no. 2, pp. 171-181, 2002.

[33] S. Giralt, R. Julià, and J. Klerkx, "Microbial biscuits of vaterite in lake Issyk-Kul (Republic of Kyrgyzstan)," Journal of Sedimentary Research, vol. 71, no. 3, pp. 430-435, 2001.

[34] Q. Zhao, L. Li, C. Li, M. Li, F. Amini, and H. Zhang, "Factors affecting improvement of engineering properties of MICPtreated soil catalyzed by bacteria and urease," Journal of Materials in Civil Engineering, vol. 26, no. 12, 2014.

[35] L. Van Paassen, M. Harkes, G. Van Zwieten, W. Van der Zon, W. Van Der Star, and M. Van Loosdrecht, "Scale up of BioGrout: a biological ground reinforcement method," in Proceedings of the 17th International Conference on Soil Mechanics and Geotechnical Engineering, pp. 2328-2333, Alexandria, Egypt, October 2009.

[36] M. P. Harkes, L. A. Van Paassen, J. L. Booster, V. S. Whiffin, and M. C. M. van Loosdrecht, "Fixation and distribution of bacterial activity in sand to induce carbonate precipitation for ground reinforcement," Ecological Engineering, vol. 36, no. 2, pp. 112-117, 2010. 